\title{
Televised Entrepreneurial Discourse: Conversational Structure and Compliance Gaining Strategies
}

\author{
Antonio García-Gómez \\ Correspondence: Antonio García-Gómez, Facultad de Filosofía y Letras. Departamento de Filología Moderna. c/ \\ Trinidad 3, 28801, Alcalá de Henares, Madrid, Spain.
}

Received: April 11, 2017

doi:10.11114/smc.v5i1.2426

\author{
Accepted: May 15, 2017 \\ Online Published: May 16, 2017
}

URL: https://doi.org/10.11114/smc.v5i1.2426

\begin{abstract}
Discourse analysis has focused extensively on argumentative and manipulative discourse. In particular, this present paper considers the different information-processing constraints at play in comprehending elicitations and responses and their role in the persuasive success of arguments. I use both a quantitative and qualitative method to examine in detail the pragma-discursive strategies employed by a panel of English and Spanish business experts in negotiating a business proposal with an entrepreneur in a media driven event. My data suggest that both British and Spanish panels of experts exploit a specific number of social influence tactics, mainly based on the use of elicit: agree, that makes it possible to identify why the interaction is successful. It is further suggested that the study of the basic unit of conversational organisation may throw light on the effectiveness of positioning oneself and others in discourse and show how British and Spanish business experts attempt to exert social influence.
\end{abstract}

Keywords: persuasion, televised business discourse, contrastive studies, compliance gaining strategies, turn-taking

\section{Introduction}

Even though public argumentation cannot be said to be a new phenomenon, televised versions of business discourse where two parties are negotiating a contract are novel as this talk has been mainly reserved for the private sphere (Barton, 2009; Anderson \& Warren, 2011). The present study offers a conversation analytic perspective of the persuasive discourse that occupies this public arena (Fahnestock (2011). In doing so, I focus on a specific aspect of televised business discourse: the intricate relationships between the institutional processes of reality television and the interactional process and the play of power of persuasive discourse (Coughter, 2012).

In the context of reality television, I first purport to identify the distinctive persuasive resources available to and employed by a panel of English and Spanish business experts to negotiate a business contract and reach an agreement with their interlocutors. Second, I attempt to explore the relationships between the social influence techniques employed and the institutional features of reality television programmes, as a social setting in which arguments and confrontation usually take place (García-Gómez, 2012). In the belief that the sequential orientation of conversation analysis can be used to throw light on power relations in discourse (Hutchby, 1996), I also intend to show how a three-part exchange understood as the basic unit of conversational organisation - is at the root of the different social influence techniques found in this setting. In what follows, these preliminary considerations will be given careful thought.

\section{Entrepreneurial Discourse, Performance and Context}

This article focuses on the talk of a panel of British and Spanish business experts in public participation broadcasting on TV and the production of "authentic" talk within this mediated context. More specifically, I consider this specific kind of talk (i.e. televised business discourse) as a species of broadcast talk. Before I turn to the following section, it will be useful to make three preliminary points about this specific type of televised business discourse that will be relevant to fully understand the analysis:

The first point is simply that televised business discourse must be understood as institutional insofar as it is actually produced in an institutional setting (Slater, 2010). It is worth pointing out that this particular kind of talk shows some resemblance with the patterns of verbal interaction normally found in everyday conversation (Gregori-Signes, 2000). Secondly, one may think that the focus becomes on how an audience makes sense of this kind of talk; that is, the discourse is then understood as one of performance and represents an attempt to provide a 'naturalness' that can be viewed by an outside set of observers (Tolson, 2013). Although no one can deny this is produced for, and oriented 
toward, an "overhearing" audience which is not co-present, the literature acknowledges the entertainment function of these programmes, but also highlights there is far much more going on than intriguing and maintaining an audience as a public function. In this case in particular, I understand the discussion part of the programme as an example of "fresh talk" (Goffman, 1961) insofar as it offers the space for opinion giving, discussion and conflict (García-Gómez, 2012).

Thirdly and although the turn-taking patterns of institutional discourse has been thoroughly discussed and the main differences from ordinary conversation pointed out (Drew \& Heritage 1992; among many others), the interaction between business experts and entrepreneurs is predetermined insofar as these experts are the ones who ask questions, whereas entrepreneurs usually answer then (Klaff, 2011). However, this pre-allocation of turns is not necessarily dependent on the context itself as these interactants are likely to keep these roles even if this negotiation took place privately in an office without the presence of an "overhearing audience". What is at stake here is the fact that the particular asymmetrical discourse is not necessarily the result of the institutional setting in which the talk takes place, but the asymmetry of power resulting from the entrepreneurs' need to get the business experts' money (O'Connor, 2004).

In addition to this, while the interaction is taking place, there is no host who may intervene, but experts and entrepreneurs are free to engage in the conversation. In fact, the absence of a host makes it possible to suggest that the format itself offers a context in which both parties can self-select. In the light of this, I argue that the nature of the programme makes this kind of talk one that is not, as such, performed, or at least, as Gregori-Signes suggests (2000), this particular televised business discourse can be said to have a quasi-conversational nature (e.g. false starts, interruptions, mistakes, informal language structures are common). As Tolson himself points out (2001: 30), this talk can be analysed 'as a form of play with the pragmatic expectations of conversational practice'.

Even though the programme may have been edited, the transactional nature that characterises this type of talk authenticates both experts' and entrepreneurs' roles as participants in relatively spontaneous and unscripted mediated events. In spite of the entertainment through talk that characterises reality television in general, the discursive strategies are not substantially different from everyday conversation (Haarman, 2001). In particular, I understand this particular type of interaction as institutional talk that can be explored from a conversation analysis point of view in order to identify systematic pragma-discursive features. The role of context, in accordance with Fairclough's (1995) cultural-generic approach, is then considered as the way to fully understand how meaning is constructed (Hill, 2017). In this context, I therefore contrast how British and Spanish business experts employ a distinctive set of social influence techniques that, apart from entertaining the audience, will help interactants reach a real business contract.

\section{Method}

\subsection{Televised Entrepreneurial Discourse: Selection Process}

As O'Leary explains (2008), an elevator pitch is a short, concise overview of a product, a particular service or a project that is aimed at persuading a potential investor in the time it takes to ride an elevator (Baron, 2008). The concept itself has to do with an accidental meeting with a potential investor in the elevator (Gallo, 2012). If that brief conversational exchange is effective, it may catch the interlocutor's interest and create the need to know more about that product. Owing to these time constraints, an elevator pitch must go straight to the point, stay at a high level and focus on what really matters: 'What is it? Who needs it? Who are the competitors? What is the competitive advantage over these competitors? How do you expect to make money?' In order to persuade potential investors why they should believe what the speaker is saying, an effective elevator pitch must also create the kind of emotional attraction that will make potential investors want to buy that idea.

In addition to a growing body of literature exploring the nature of an effective elevator pitch as well as popular press articles and information that aim to give tips for crafting an effective elevator pitch (cf. Sedniev, 2016), national and international competitions have gained popularity among professionals and university students. Given that the aim of the present paper was to explore the relationship between the presence of a specific structural interaction pattern and its influence on the effectiveness of a particular social influence, I decided to opt for Dragon's Den: one of the most popular television programmes both in the British and the Spanish television that based its success in the persuasive skills of entrepreneurs who try to sell a product to panel of investors (Slater, 2010; and Spalton, 2010).

More specifically, Dragon's Den was first launched in Japan and it is now an international brand with versions airing in UK and Spain ('Tu Oportunidad') among many other countries in the world. In both the British and the Spanish version of the programme, entrepreneurs' pitch must be persuasive enough so as to convince a panel of business experts that comprises three male and two female venture investors who are willing to invest their own money in exchange for equity (Slater, 2010). After introducing themselves entrepreneurs have no longer than three minutes to explain the ins and outs of their business, ask for a specific amount of money in exchange for a specific percentage of equity. Once the investor pitch is over, the Dragons ask questions to get all the necessary details to negotiate the business proposal and make a decision. 
After having answered the questions posed, the Dragons can declare themselves 'out' if they are not interested. If this happens, they must remain silent and they will not re-enter negotiation on the deal. Those interested offer an amount of money, which can be negotiated so that the entrepreneur can secure the total amount he or she asked for at the beginning of the pitch. Even though each Dragon is an individual investor, the entrepreneur may seek investment from more than one Dragon and persuade them to invest a portion of the total amount of money needed. Finally, entrepreneurs are free to accept or refuse investment if they think the deal does not satisfy their financial needs.

\subsection{Data Selection and Classification Process}

As for the data selection, a content analysis of all programmes broadcast in the first two series was conducted. The selective representation was done in terms of two key variables: 1) Gender. Five female and five male entrepreneurs were selected from each group; and 2) Similar business proposal. Furthermore, entrepreneurs were asking for a similar amount of money in exchange for a similar percentage of the business. In the end, I selected a total number of 10 business pitches from both the British and the Spanish versions of the programme .

The second stage of the analysis focused on understanding the illocutionary force embedded within the Dragons' elicitations in the belief that the discourse analysis of these elicitations will cast light on the persuasive nature of the interaction. Therefore, elicitations were coded for their pragmatic meaning and classified into a consistent and manageable taxonomy of 4 principles of classification of main communication acts in the British and the Spanish data: inform (i.e. elicit the entrepreneur to provide new information), agree (i.e. elicit the entrepreneur to agree with the Dragon's requests), clarify (i.e. elicit the entrepreneur to clarify a particular aspect), and commit (i.e. invite the entrepreneur to show commitment of some kind). Table 1 below shows the principles of classification of elicitations found in the corpus and frequency of each pragmatic meaning.

Table 1. Principles of classification of initiating moves: elicitations in the corpus. Adapted from Tsui (1994)

\begin{tabular}{llllll}
\hline & & British & Corpus & Spanish & Corpus \\
\hline Initiating move: & Frequency & Percentage & Frequency & Percentage \\
Elicit: & Male business expert & 439 & $26 \%$ & 461 & $23.8 \%$ \\
agree & Female business expert & 557 & $33 \%$ & 676 & $34.9 \%$ \\
Elicit: & Male business expert & 36 & $2.1 \%$ & 29 & $1.4 \%$ \\
clarify & Female business expert & 25 & $1.4 \%$ & 30 & $1.5 \%$ \\
Elicit: & Male business expert & 65 & $3.8 \%$ & 47 & $2.4 \%$ \\
commit & Female business expert & 41 & $2.4 \%$ & 44 & $2.2 \%$ \\
Elicit: & Male business expert & 236 & $13.9 \%$ & 312 & $16.1 \%$ \\
inform & Female business expert & 288 & $17 \%$ & 335 & $17.3 \%$ \\
& Total & 1,687 & & 1,934 & \\
\hline
\end{tabular}

The third stage consisted in gaining insights from the data by relating the illocutionary force of the Dragon's elicitations to the nature of the entrepreneurs' responses. That is to say, a quantitative analysis was carried out in order to identify whether or not there seemed to be a systematic correspondence between a particular type of elicitation and response (i.e. either a responding or a challenging act). In addition to this, I conducted a statistical analysis of the presence of a third-part or follow-up move in order to address any possible correlation between the type of elicitation and/or response and the presence of a follow-up move. Finally, the gender variable was also considered in order to identify whether male or female business experts were more prone to exploit a particular type of elicitation and produce a follow-up move in each culture.

Below, table 2 shows the structural pattern under analysis that comprises three different moves: (1) the initiating move consists in an elicitation that is produced by either a male or a female business expert; (2) the responding move is produced by a male or a female entrepreneur and may be realised by either a responding act or a challenging move; and (3) the presence or absence of a follow-up move produced by the very same interlocutor that produced the initiating move. For the sake of clarity, I will discuss these aspects in detail as well as I will offer the specific quantitative analysis as section 4 unfolds. 
Table 2. Analysis of the basic unit of conversational organization in televised business negotiations

\begin{tabular}{|c|c|c|c|c|}
\hline \multicolumn{2}{|c|}{$\begin{array}{l}\text { British and Spanish data } \\
\quad \text { Business expert } \\
\text { Initiating move: Elicitations }\end{array}$} & \multicolumn{2}{|c|}{$\begin{array}{l}\text { Entrepreneur } \\
\text { Responding } \\
\text { Move }\end{array}$} & \multirow[t]{2}{*}{$\begin{array}{l}\text { Business expert } \\
\text { Presence of a } \\
\text { follow-up move }\end{array}$} \\
\hline \multirow{2}{*}{\multicolumn{2}{|c|}{ Men }} & $\mathrm{M}$ & Responding act & \\
\hline & & $\mathrm{W}$ & Challenging act & Yes/No \\
\hline \multirow[t]{2}{*}{ Women } & Elicit: agree & M & Responding act & \\
\hline & & $\mathrm{W}$ & Challenging act & Yes/No \\
\hline \multirow{2}{*}{ Men } & & $\mathrm{M}$ & Responding act & \\
\hline & & $\mathrm{W}$ & Challenging act & Yes/No \\
\hline \multirow[t]{2}{*}{ Women } & Elicit: clarify & $\mathrm{M}$ & Responding act & \\
\hline & & $\mathrm{W}$ & Challenging act & Yes/No \\
\hline \multirow[t]{2}{*}{ Men } & & M & Responding act & \\
\hline & & $\mathrm{W}$ & Challenging act & Yes/No \\
\hline \multirow[t]{2}{*}{ Women } & Elicit: commit & M & Responding act & \\
\hline & & $\mathrm{W}$ & Challenging act & Yes/No \\
\hline \multirow[t]{2}{*}{ Men } & & M & Responding act & \\
\hline & & $\mathrm{W}$ & Challenging act & Yes/No \\
\hline \multirow{2}{*}{ Women } & Elicit: inform & M & Responding act & \\
\hline & & $\mathrm{W}$ & Challenging act & Yes/No \\
\hline
\end{tabular}

\section{Analysis}

\subsection{Uncovering the Basic Unit of Conversational Organisation in Televised Business Discourse}

After having elicited information that could be missing in the monologue (i.e. elicit: inform) and having asked for clarification whenever needed (i.e. elicit: clarify), inspection of the data shows that both British and Spanish Dragons tend to exploit a significant higher number of elicit: agree during their interaction (see tables $3 \& 4$ above). Furthermore, the negotiation unfolds as a consistent sequence of three-part exchanges that shows a consistent set of characteristics. The following tables give the number of three-part exchanges initiated by elicit: agree in the data. In order to give a full account of any consistent structural pattern in the turn-taking system, the quantitative analysis reflects whether or not these elicitations were followed by responding or challenging acts. It also shows the presence or absence of the follow-up move. It is important to note that the gender variable was considered when quantifying the three moves the exchange consists of.

Table 3. Basic unit of conversational organisation in the British data: Three-part exchange

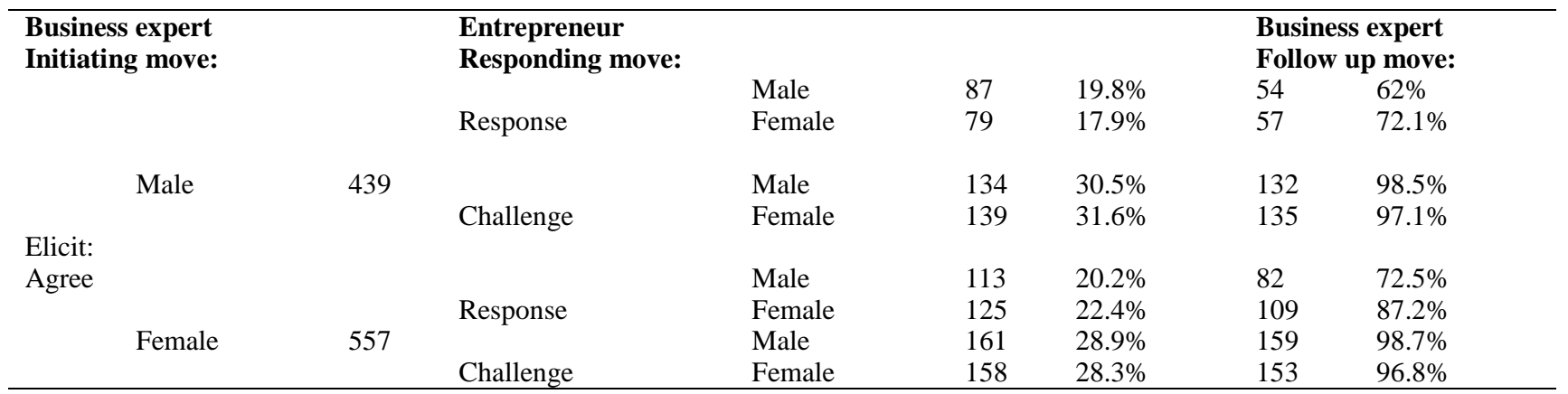

Table 4. Basic unit of conversational organisation in the Spanish data: Three-part exchange

\begin{tabular}{|c|c|c|c|c|c|c|c|}
\hline \multicolumn{2}{|l|}{$\begin{array}{l}\text { Business expert } \\
\text { Initiating move: }\end{array}$} & \multicolumn{4}{|c|}{$\begin{array}{l}\text { Entrepreneur } \\
\text { Responding move: }\end{array}$} & \multicolumn{2}{|c|}{$\begin{array}{l}\text { Business expert } \\
\text { Follow up move: }\end{array}$} \\
\hline \multirow{6}{*}{$\begin{array}{l}\text { Elicit: } \\
\text { Agree }\end{array}$} & \multirow{6}{*}{461} & & Male & 155 & $33.6 \%$ & 55 & $35.4 \%$ \\
\hline & & Response & Female & 127 & $27.5 \%$ & 91 & $71.6 \%$ \\
\hline & & & Male & 102 & $22.1 \%$ & 93 & $91.1 \%$ \\
\hline & & Challenge & Female & 77 & $29 \%$ & 72 & $93.5 \%$ \\
\hline & & & Male & 134 & $19.8 \%$ & 79 & $58.9 \%$ \\
\hline & & Response & Female & 248 & $36.6 \%$ & 195 & $78.6 \%$ \\
\hline \multirow[t]{2}{*}{ Female } & 676 & & Male & 131 & $19.3 \%$ & 127 & $96.9 \%$ \\
\hline & & Challenge & Female & 163 & $24.1 \%$ & 151 & $92.6 \%$ \\
\hline
\end{tabular}

The consistent pattern tables 3 and 4 reveal can be explained as follows:

1. Initiating move. Elicit: agree. Both British and Spanish Dragons produce a particular first part in the form of an 
elicitation, which sets up the expectation of a particular second pair part in the form of a response. What is of interest here is the fact that the specific norms that give structure to the interaction seem to be based on a 'disconfirmation bias in argument evaluation' (Hogg and Vaughan, 2008: 207); that is to say, in the light of their evaluative beliefs (i.e. their judgement or appraisal about the product), the Dragons tend to exploit these elicitations in order to invite the entrepreneur to supply a piece of information and to scrutinise those arguments that seem to be incompatible with their own prior beliefs.

Furthermore, I suggest that the use of elicit: agree seems to have a persuasive effect as they aim to enhance the positivity of the Dragons' self-concept by performing a biased search of knowledge to support a favourable self-concept (i.e. showing interest in the entrepreneur's product) and contribute to a positive sense of in-group membership ('You and I as potential business partners'). Finally, it is worth highlighting the fact that female Dragons tend to elicit: agree more can explain why four out of the five Spanish female Dragons eventually made an offer and the only three British Dragons who reached an agreement were female. All in all, the analysis suggests that elicit: agree work at an interpersonal level since these elicitations aim to build rapport and gain compliance from entrepreneurs.

(1) Tu Oportunidad

A: ¿Te parece bien si te ofrezco 30.000 euros for un 20\%? ((What do you think if I give 30.000 euros in exchange for 205))

B: Con eso tendría suficiente para arrancar ((That'd be good enough to start))

A: Eres mío ¿Hacemos trato entonces? ((You're mine. Deal?))

B: Sí, sí, trato hecho. ((Yes, yes, deal!))

A: Hoy es tu día de suerte ((Today is your lucky day))

A/B: ((Smile and shake hands)

(2) Tu Oportunidad

A: Me parece bastante interesante todo lo que nos has contado y por ello te doy todo el dinero que pides por la mitad del negocio. ¿Te hace? ¿hacemos trato entonces? ((I think what you've told us is fairly intesting and that's why I give you all the money you asked for in exchange for $50 \%$ of the business. Do you agree? Deal?))

B: Eso es demasiado ((That's too much))

A: Piensatelo bien. Todo el dinero que necesitas y la mitad del negocio yo lo aceptaría si fuera tú. ¿Trato hecho? ((Think it about it. I offer you all the money you need and half of your business. I'd accept it if I were you. Deal?))

B: No es justo ((This is not a fair offer))

A: Estoy fuera ((I'm out))

(3) Dragon's Den

A: How about if we keep the $5 \%$ in the business then because we have also registered in the UK then the $\mathbf{2 0} \%$ that you want you can have that in the UK market to give you the drive to be the... dunno.

B: So you would offer a higher than $5 \%$ in the UK company. It would be a subsidiary of the Australian company. That'd be a good deal

A: Good. Agree?

B: I'm very happy

A: Glad to hear it. We'll do great things together

B: Sure

A/B: ((they shake hands)

(4) Dragon's Den

A: I am going to offer you all the 40,000 pounds. But I would like $20 \%$ of your business. And the reason why $I$ have asked for $20 \%$ is that I do crack fro you the main retailers then it could be big and if it is big then I will have helped you create that

B: Ok thank you 
A: Umm are you accepting?

B: I don't know

A: I am not making any other offer this one is a fair offer. Deal?

B: I don't think so.

A: going one going...

B: I can’t

A: You don't know what you're talking about. I'm out.

2. Responding move. These elicitations can either be followed by:

(i) a responding act (i.e. the entrepreneur fulfils the illocutionary force with which the elicitation was produced; that is, the piece of information provided is in accordance with the Dragon's evaluative beliefs).

(5) Tu Oportunidad

A: ¿Aceptas si te ofrezco ahora mismo la mitad de lo que has pedido por un 35\% de tu negocio? ((Do you accept if I give you right now half of what you have asked in exchange for $35 \%$ of your business?))

B: Claro, es una buena oferta ((Sure, this is a good offer))

A: Me alegro por ti ((Good for you))

A/B: ((they shake hands))

(6) Dragon's Den

A: You know I believe in your idea. I offer you 35,000 but I'd like 35\% of your business. What do you say?

B: What can say? Yes with my eyes closed ((Laughing))

A: Deal

A/B: ((they shake hands))

(ii) a challenging act (i.e. the entrepreneur does not fulfil the illocutionary force of the elicitation and, therefore, challenges the Dragon's evaluative beliefs).

(7) Tu Oportunidad

A: Te ofrezco un cuarto del dinero y un $20 \%$ del negocio y si en el futuro veo que la cosa progresa podríamos renegociarlo $i$ Te parece? ((I offer you a fourth of the money you need and I'd like $20 \%$ of the business. If later on I can see things are going well, we could renegotiate it. What do you think?))

B: No, no, un cuarto es poco ((No, no, a fourth is not enough))

A: No sabes lo que dices. Un cuarto por $20 \%$ es lo mejor que vas a poder conseguir. ¿Aceptas? ((You don't know what you're saying. A fourth of the business in exchange for $20 \%$ is the best offer you can get. Do you accept it?))

A: No me temo que ((No, I'm afraid I))

B: Estoy fuera ((I'm out))

(8) Dragon's Den

A: There is a number of things we still have to discuss but I offer you 25,000 but I'd like $30 \%$ of your business. Interested?

\section{B: I'd like to give as much as I take}

A: You need me more than I need you. 30,000 in exchange for 35\%. Does this offer suit your plans?

B: Not really

A: I'm out

B: The thing is...

A: I'm out

Although there does not seem to be a statistically significant gender-based preference for the production of responses or challenges, it is possible to draw a line between British and Spanish entrepreneurs. It is important to note that, in the 
data, British entrepreneurs do tend to challenge the Dragons' elicitations (59.4\%) more than the Spanish ones (41\%). This tendency is also in line with a lesser business proposal acceptance rate in the British data.

3. Follow-up move. Without any doubt, the high percentage of follow-up moves in the exchange are revealing for my research purposes. Given that the follow-up move is present in more than $60 \%$ of the exchanges, it can be claimed that the persuasive nature of the interaction makes the exchange to be seen as incomplete and a further contribution is required on the part of the Dragon. More specifically, the quantitative analysis shows that the follow-up move is not only much more frequent after a challenging move as it is present in more than $90 \%$ of the exchanges, but also female Dragons tend to produce this move slightly more than the male ones - even if the entrepreneurs responded their elicitations. With regard to the function of this follow-up move, the follow-up move is used to evaluate the product positively if the entrepreneur responds or, on the contrary, this third move shows how the entrepreneur has not produced an acceptable response. In doing so, the Dragons attempt to recover the intention of the first move by complaining, insisting on the former idea, and/or evaluating the product/the entrepreneur's attitude negatively.

(9) Tu Oportunidad

A: ¿Te parece bien si te ofrezco 30.000 euros for un 20\%? ((What do you think if I give 30.000 euros in exchange for 205))

B: Con eso tendría suficiente para arrancar ((That'd be good enough to start))

A: Eres mío ¿Hacemos trato entonces? ((You’re mine. Deal?))

B: Sí, sí, trato hecho. ((Yes, yes, deal!))

A: Hoy es tu día de suerte ((Today is your lucky day))

A/B: ((Smile and shake hands)

(10) Tu Oportunidad

A: Te ofrezco un cuarto del dinero y un $20 \%$ del negocio y si en el futuro veo que la cosa progresa podríamos renegociarlo $i$ Te parece? ((I offer you a fourth of the money you need and I'd like $20 \%$ of the business. If later on I can see things are going well, we could renegotiate it. What do you think?))

B: No, no, un cuarto es poco ((No, no, a fourth is not enough))

A: No sabes lo que dices. Un cuarto por $20 \%$ es lo mejor que vas a poder conseguir. ¿Aceptas? ((You don't know what you're saying. A fourth of the business in exchange for $20 \%$ is the best offer you can get. Do you accept it?))

A: No me temo que ((No, I'm afraid I))

B: Estoy fuera ((I'm out))

(11) Dragon's Den

A: There is a number of things we still have to discuss but I offer you 25,000 but I'd like $30 \%$ of your business. Interested?

B: I'd like to give as much as I take

A: You need me more than I need you. 30,000 in exchange for 35\%. Does this offer suit your plans?

B: Not really

A: I'm out

B: The thing is...

A: I'm out

(12) Dragon's Den

A: I am going to offer you all the 40,000 pounds. But I would like $20 \%$ of your business. And the reason why I have asked for $20 \%$ is that I do crack fro you the main retailers then it could be big and if it is big then I will have helped you create that

B: Ok thank you

A: Umm are you accepting?

B: I don't know

A: I am not making any other offer this one is a fair offer. Deal? 
B: I don't think so.

A: going one going...

B: I can't

\section{A: You don't know what you're talking about. I'm out.}

Finally, the fact of identifying the basic unit of conversational organisation in the data makes it possible to argue that the way the turn-taking system is distributed determines the way British and Spanish Dragons relate to the entrepreneurs. Given that cooperation plays an important role in the process of persuasion, the use of elicit: agree not only helps the Dragons treat entrepreneurs as in-group members, but also the fact that entrepreneurs are required to agree subtly enlist social pressure to accept the Dragons' requests. These requests do not usually correspond with the entrepreneur's initial proposal.

In what follows, I will concern myself with a pragma-discursive analysis of these three-part exchanges in an attempt to gain insights into the persuasive nature of the interaction.

\subsection{Performing Strategies for Gaining Compliance in Televised Business Discourse}

If the use of elicit: agree works as a persuasive strategy, some important questions remain answered: (1) Given that the success of each business pitch varies from one entrepreneur to another, would the study of the sequences of elicit: agree make it possible to throw light on the way(s) British and Spanish Dragons relate to the entrepreneurs (i.e. by scrutinising their business proposals)? And in doing so, would the pragma-discursive analysis of elicit: agree make it possible to uncover the complex persuasive strategies being used by these business experts in order to gain compliance?; (2) The quantitative analysis reveals that, independently from the culture and the gender variable, elicit: agree are sometimes followed by a responding or a challenging act. Thus, one may pose the questions: Would it be possible to gain insight into the pragmatic motivations that provoke the presence of each responding move? Besides, what are the pragmatic motivations of a follow-up move after both types of responding move?

As the analysis will show, the interactional dynamics of the business experts and entrepreneurs' interaction can be considered as an example of 'live-event' broadcasting insofar as this reality television programme that involves, as argued above, features of spontaneous talk. In accordance with Hutchy (2001), I understand that the persuasive nature of the interaction and the potential confrontations is not a pre-existing element that shapes their interventions during the negotiation of the contract.

Inspection of the data gives evidence that the use of elicit: agree responds to three basic persuasive tactics: (1) Foot-in-the-door tactic; (2) Door-in-the-face tactic; and (3) Low-ball tactic (Freedman and Fraser, 1966). These three persuasive tactics not only help British and Spanish Dragons to scrutinise entrepreneurs' business proposal, but also they subtly enlist social pressure and urge entrepreneurs to agree with the Dragon and, consequently, accept their request. Let us discuss each tactic in turn.

4.2.1 Tu Oportunidad: Persuading Others and the Foot-in-the-door Tactic

In the case of the Spanish data, the five male and female Dragons use the foot-in-the-door tactic as an attempt to establish common ground between them and the entrepreneurs (Tsui, 1994: 87), promote social 'mutuality' (Brazil, 1984: 34) and be able to reach an agreement that benefits them. The following examplee illustrate how the Dragon first elicits some further information (i.e. elicit: inform) he requires to make a decision and then exploits a succession of elicit: agree which responds to this persuasive tactic.

Extract 1

Male business expert (A): No sé si te he entendido bien ¿Cuántos años lleváis con este proyecto? ((I don ’t know whether I got you right. How long have you been working on this project?))

Male Entrepreneur (B): Llevamos en ello casi cuatro años y tenemos ganancias casi desde el primer día ((Almost four years and we've made profit almost from day one.))

A: Eso está muy bien. ¿Qué te parece entonces si me uno a vuestro plan y me cedes un 20\% por 38.000 euros? ((This is great. What do you think if I join you and you give me $20 \%$ in exchange for 38,000 euros?))

B: Sí, sí, claro, me parece bien. ((Yes, of cours, that'd be great))

A: Lo sabía. ¿Qué te parece entonces si te doblo la oferta por la mitad de tu negocio? ((I knew it. What do you think then I double the offer in exchange for half of the business?))

B: No era lo que había pensado. ((This is not what I'd planned))

A: Sabes que me quieres dentro ¿Lideramos al proyecto a medias y te cubro mucho más de lo que pediste? ((You know 
you want me in. Do we head the project as a team and I give you much more than you asked for?))

B: Sí, creo que no puedo decir que no. Realmente no puedo decir que no ((Yes, I think I cannot refuse your offer. I can 't really say no to your offer))

A: No, no puedes. ¿Hacemos trato? ((No, you can't. Deal?))

B: Trato echo ((Deal))

A: ((Sonrie, se levanta y le da la mano)) ((He smiles, stands up and they shake hands))

As can be seen this extract, the effectiveness of this tactic (Dolinski, 2000) lies on the fact that if the Dragon gets the entrepreneur to agree to a small request (e.g. "What do you think if I join you and you give me $20 \%$ in exchange for 38,000 euros?"), they will later be more willing to comply with a large request (e.g. "What do you think then I double the offer in exchange for half of the business?"). Inspection of the data shows that business experts first elicit some further information that was missing in the entrepreneurs' previous monologue (e.g. "I don't know whether I got you right. How long have you been working on this project?"). After having all the necessary details, Dragons show their interest in the business proposal and invite the entrepreneurs to agree with a small request (i.e. having a higher percentage and offering half of the money initially proposed).

With regard to the structural pattern of the interaction, it can be noticed, as extract 1 illustrates, that Dragons tend to produce an endorsing follow-up move (Tsui, 1994: 200) in order to upgrade the agreement (Pomerantz, 1984: 68), even though both elicitations are followed by a responding act (e.g. "This is great"; "You know you want me in")

As mentioned above, only three business proposals in the Spanish data did not succeed. In spite of the fact that the Dragons exploit the very same persuasive tactic, the difference lies in the fact that the entrepreneurs challenged the initiating move. In doing so, entrepreneurs question the Dragons' authority and/or knowledge of the market and they usually provoke their anger and they end up declaring themselves out. Even though the interaction unfolds as a succession of three-part exchanges, the follow-up move fulfils a different discursive function as it encodes the Dragon's attitudinal meaning: a negative appraisal of the entrepreneur's decision and/or product on one hand and their anger and/or disappointment on the other. Let us consider the following extract:

Extract 2

Male business expert (A): ¿y desde cuándo estáis con el negocio? ((when did you start your business?))

Female entrepreneur (B): arrancamos el año pasado ((We started last year))

A: estoy dispuesto a participar en la idea, sin duda, ¿estarías dispuesta a dejarte asesorar para ver cómo atendemos el mercado internacional? ((I'm willing to be part of the project, without any doubt, would you accept my advise to see how we understand the international market?))

B: sí, claro. Eso sería extraordinario ((Yes, of course. That'd be extraordinary))

A: ¿qué te parece entonces si cubro la cantidad que solicitas pero a cambio cedes el $50 \%$ de la empresa? ((What do you think if I give you the money you asked for in exchange of 50\%))

B: ((se queda callada)) Esa no era mi idea original (([She remains silent] That was not my original idea))

A: Lo sé ¿aceptarías mi propuesta si pongo en tus manos mi equipo de asesores? ¿hacemos trato? ((I know. Would you accept my offer if I let you talk to my advisors? Deal?))

B: No, no lo considero necesario, prefiero esperar e intentarlo de otra forma. ((No, I don't think that's necessary. I prefer waiting and trying to do it some other way))

A: Estoy fuera entonces ((I'm out then))

Finally, it is worth pointing out that the foot-in-the-door technique works on the principle of consistency (Petrova et al., 2007). The Spanish data reveal that this persuasive tactic does not work in these particular three cases insofar as the second elicit: agree is not consistent with or similar in nature to the original small request embedded within the first elicit: agree. Extract 2 illustrates this point and shows how this Dragon goes from offering some technical expertise to lending the money required in exchange for $50 \%$ of the company shares instead of $15 \%$.

\subsubsection{Dragon's Den: Persuading Others and the Door-in-the-face and Low-ball Tactics}

Inspection of the 10 British pitches gives evidence that elicit: agree also work as a persuasive tactic. However, these British male and female Dragons mainly rely on the door-in-the-face tactic. Interestingly enough, they tend to exploit this persuasive tactic when they are interested in the business proposal, but they are mainly concerned with negotiating the economic offer and, thus, getting only part of the business for a cheaper price. In spite of the Dragons' persuasive 
efforts, the tactic seems to fail insofar as none of the Dragons who used this tactic succeeded in persuading the entrepreneur to accept their economic offer. Consider the following extract:

Extract 3

Male business expert (A): What other ideas do you have to get money from this site? I mean if you have any

Female entrepreneur (B): So far we haven't explored any other possibilities, but we are open new ideas.

A: Sure I've got lots of ideas. I'm positive your project can have a great impact on the international market, but there are some important issues we should discuss first

B: yeah, yeah of course

A: Great. $49 \%$ and 60.000 ?

B: Just to clarify. Are you saying that you want $49 \%$ for 60.000 ?

A: That's exactly it. Do you agree on that?

B: No, I'm sorry. I mean unfortunately there is no way I can go from $30 \%$ to $49 \%$

A: You need me a lot more than I need you by miles. Deal?

B: I know but I can't

A: Very well then. $30 \%$ in exchange fro 30.000 ?

B: No, I'm sorry. That's still too much

A: I bet you don't have that money in your back pocket. Deal?

B: I certainly not, but I can't

A: Big mistake! I'm out

As extract 3 shows, the Dragon precedes the presentation of focal piece of information they want entrepreneurs to agree with by a larger request that is bound to be refused (e.g. " $49 \%$ and 60.000 ?"). As expected, the entrepreneur challenges the illocutionary force of the elicitation (e.g. "No, I'm sorry. I mean unfortunately there is no way I can go from $30 \%$ to $49 \%$ "). After the entrepreneur has refused the offer, the Dragon introduces the real offer (e.g. " $30 \%$ in exchange fro 30.000?'); however, the entrepreneur does not agree with that offer. The structural analysis of the interaction shows how the Dragon always produces a follow-up move to consolidate the exchange and, pragmatically speaking, this move encapsulates a negative assessment of the entrepreneur's challenging acts (e.g. "You need me a lot more than I need you by miles"; "Big mistake!").

The discourse analysis of the British data gives evidence that all of the challenges take place whenever these Dragons exploit the door-in-the face tactic. As a result, no agreement is reached. Interestingly enough, the only three female Dragons who persuaded the entrepreneurs used the low-ball tactic. These three Dragons induced the entrepreneurs to agree to a request before revealing certain hidden costs. Consider the following extract:

Extract 4

Female business expert (A): I don't see anything here that I couldn't do very simply very quickly myself. I can't see where it's going to generate me income. How is it gonna make money. What's the innovation?

Male entrepreneur (B): If say a group of three students are looking for a property and they find a property that's got five rooms with one click they can create a notice that appears in the housemate section in the notice board.

A: That actually diminishes your revenue actually if you think about it, doesn't it?

B: No, I don't think so

A: It does. I'm going to offer you 75,000 pounds for $15 \%$ of the business.

B: No ((nodding his head))

A: what you explained dimishes your revenue because it takes the property off the site quicker and therefore reduces. Right?

B: I don't think so.

A: You're wrong. But if you're so sure, let me make you an offer, 150,000 pounds for $15 \%$

B: That'd be great

A: Sure! But if you're right you'll give me $20 \%$ after a year 
B: Erm ((he thinks for a few seconds)) All right

A: What you're doing is right! ((they shake hands))

As extract 4 shows, the Dragon wants to make it clear that the business proposal is not so good as suggested. The effectiveness of this tactic relies on the principle once people are committed to an action, they are more likely to accept a slight increase in the cost of the action (Hogg \& Vaughan, 2008: 215). Furthermore, the thrill of the strategy lies in the implicit social sanction that elicitations encapsulate, for it undermines the entrepreneurs' product, and also regulates the disclosure of information that will make them admit its limitations and weaknesses (Billig, 1996). As suggested above, the exchanges are perceived as incomplete and the Dragon produces a negative evaluation to recover the illocutionary intent of the first initiating move and to support what she believes it is right. As a result, the Dragon's first offer is declined.

Aware of the fact that the negotiation is blocked, the Dragon seems to change the rule halfway and manages to get away with it. In particular, she offers the amount of money the entrepreneur requested. The success of the technique works on the principle of commitment (Cialdini et al., 1978). Given that the entrepreneur has agreed to the initial request, commitment has been given. When the request changes (i.e. getting a higher percentage of the business after a year), the entrepreneur finds it difficult to say "no" because of having originally committed himself. All in all, expert and informational power may be regarded as the regulatory force which determines the whole persuasive effect of the strategy and guarantees that the three Dragons in the British data achieve to reach an agreement and invest their money.

\section{Conclusion}

The study has thoroughly analysed the turn-taking norms that apply to this particular context and identified the basic unit of conversational organisation in televised business discourse. In identifying the three-part exchange, the study has made it possible to identify key structural patterns in exerting interpersonal influence. More specifically, the qualitative analysis has pointed out the fact that British and Spanish Dragons employ four types of elicitations that aim to clarify possible misunderstandings (i.e. elicit: clarify), invite commitment of some kind (i.e. elicit: commit); gain compliance by eliciting the entrepreneur to agree (i.e. elicit: agree); and gain information that will help them assess the business proposal (i.e. elicit: inform). Interestingly enough, the statistical analysis has revealed that most of the interactions between the Dragons and the entrepreneurs revolve around the use of elicit: inform and, more importantly, of elicit: agree.

Furthermore, the study has given evidence that the interaction unfolds as a consistent sequence of three-part exchanges that also show a consistent set of characteristics. Exploration of the exchange suggests that elicit: agree not only help British and Spanish Dragons relate to entrepreneurs by treating them as in-group members, but also enlist social pressure and, eventually, persuade them to accept their requests. However, a thorough pragma-discursive analysis was required to gain insights into the persuasive nature of the interaction.

In doing so, the study has been able to relate the presence of a responding or a challenging move to a specific persuasive tactic. On the one hand, Spanish Dragons' use of elicit: agree is connected to the employment of the foot-in-the-door tactic. By getting the entrepreneur to agree to a small request, they are later be more willing to comply with a large request and, eventually, reach an agreement. Owing to the success of this strategy, the entrepreneurs tend to produce responses rather than challenges and the exchange is completed with endorsing follow up moves. On the other hand, British Dragons' use of elicit: agree is either connected to the employment of the door-in-the-face tactic or the low-ball tactic. The analysis has shown how the former results in blocking the negotiations and elicit: agree are usually followed by challenging moves, whereas the latter results in reaching an agreement between both parties and elicit: agree are usually followed by responding moves. Of interest here is the fact that in both cases the exchange is perceived to be incomplete and British Dragons produce a follow up move in order to complain or insist on their previous idea (door-in-the-face tactic) or to appraise the entrepreneurs decision positively (low-ball tactic). All in all, the present study has brought together the understanding of the efficiency of influence techniques and the basic unit of conversational organisation.

\section{Acknowledgements}

The present study was financially supported by a grant (ID No: FFI2013-47792-C2-2-P) from the Ministerio de Economía y Competitividad. This article is part of the long-term research project 'EMOtion and language 'at work': The discursive emotive/evaluative FUNction in different texts and context wtithin corporate and institutional work: PROject PERsuasion (EMO-FUNDETT: PROPER) 


\section{References}

Anderson, A. R., \& Warren, L. (2011). The entrepreneur as hero and jester: enacting the entrepreneurial discourse. International Small Business Journal, 29(6), 589-609. https://doi.org/10.1177/0266242611416417

Baron, R. A. (2008). The role of affect in the entrepreneurial process. Academy of Management Review, 33(2), 328-340. https://doi.org/10.5465/AMR.2008.31193166

Barton, K. (2009). Reality Television Programming and Diverging Gratifications: The Influence of Content on Gratifications Obtained. Journal of Broadcasting \& Electronic Media, 53(3), 460-476. https://doi.org/10.1080/08838150903102659

Billig, M. (1996). Arguing and Thinking: A Rhetorical Approach to Social Psychology. Cambridge: Cambridge University Press.

Brazil, D. (1984). Tag Questions. Discourse Analysis. Ilha do Destero, 11, 93-108.

Cialdini, R., Cacioppo, J., Bassett, R., \& Miller, J. (1978). Low-ball procedure for producing compliance: commitment then cost. Journal of personality and Social Psychology, 36(5), 463-476. https://doi.org/10.1037/0022-3514.36.5.463

Coughter, P. (2012). The Art of the Pitch: Persuasion and Presentation Skills that Win Business. Palgrave Macmillan, Basingstoke. https://doi.org/10.1007/978-1-137-51233-8

Dolinski, D. (2000). On inferring one's beliefs from one's attempt and consequences for subsequent compliance. $J$. Personal. Soc. Psychol, 78, 260-272. https://doi.org/10.1037/0022-3514.78.2.260

Drew, P., \& Heritage, J. (Eds.) (1992). Talk at work. Interaction in institutional settings. Cambridge: Cambridge University Press.

Fahnestock, J. (2011). Rhetorical Style: The Uses of Language in Persuasion. Oxford University Press, Oxford. https://doi.org/10.1093/acprof:oso/9780199764129.001.0001

Fairclough, N. (1995). Media Discourse. London: Edward Arnold.

Freedman, J., \& Fraser, S. (1966). Compliance without pressure: The foot-in-the-door technique Journal of Personality and Social Psychology, 4, 195-202. https://doi.org/10.1037/h0023552

Gallo, C. (2012). "How to pitch anything in 15 seconds". Available at: www.forbes.com/sites/carminegallo/2012/07/17/how-to-pitch-anything-in-15-seconds/

García-Gómez, A. (2012). Perceptions of assertiveness among women: Triggering and managing conflict in reality television. Discourse and Communication, 6(4), 1-21.

Goffman, E. (1961). Encounters: two studies in the sociology of interaction. Bobbs-Merrill.

Gregori-Signes, C. (2000). The tabloid Talkshow a quasi-conversational type of facte-to-face interaction, Pragmatics, 10(2), 195-213. https://doi.org/10.1075/prag.10.2.02gre

Haarman, L. (2001). Performing Talk. In A. Tolson (ed.) Television Talk Shows. Discourse, Performance, Spectacle (pp. 31-64). Mahwah, N.J.: Erlbaum.

Hill, A. (2017). Reality Television Experiences: Audiences, Facts and Fictions. In L. Ouellette (ed.) A Companion to Reality Television (pp-116-133). London: Blackwell.

Hogg, M., \& Vaughan, G. (2008). Social psychology. Essex: Pearson Education.

Hutchby I. (1996). Confrontation talk: Arguments, Asymmetries and Power on Talk Radio. Hillsdale, N.J.: Erlbaum.

Klaff, O. (2011). Pitch Anything: An Innovative Method for Presenting, Persuading, and Winning the Deal. New York: NY.

O'Connor, E. (2004). Storytelling to be real: narrative, legitimacy building and venturing. In D. Jorth and C. Steyaert (Eds.), Narrative and Discursive Approaches to Entrepreneurship (pp.105-124). Elgar, Northampton, MA. https://doi.org/10.4337/9781845421472.00011

O’Leary, C. (2008). Elevator Pitch Essentials: How to Get Your Point Across in Two Minutes or Less. London: The limb press.

Petrova, P., Cialdini, R., \& Sills, S. (2007). Consistency-based compliance across cultures. Journal of Experimental Social Psychology, 43(1), 104-111. https://doi.org/10.1016/j.jesp.2005.04.002

Pomerantz, A. (1984). Agreeing and disagreeing with assessments: some features of preferred/dispreferred turn shapes. 
In J.M. Atkinson \& J. Heritage (Eds.) Structures of Social Action (pp.57-101). Cambridge: Cambridge University Press.

Sedniev, A. (2016). Magic of Public Speaking: A Complete System to Become a World Class Speaker. Published at magicofpublicspeaking.com

Slater, R. (2010). Dragons'Den: Start Your Own Business: From Idea to Income. Harper Collins Publishers, London.

Spalton, P. (2010). Dragons' Den: The Perfect Pitch: How to Win Over an Audience? Harper Collins Publishers, London.

Thornborrow, J. (2001). Authenticating talk: building public identities in audience participation broadcasting. Discourse Studies, 3(4), 459 - 479. https://doi.org/10.1177/1461445601003004008

Tolson, A. (2001). Talking About Talk: The Academic Debates. In A. Tolson (ed.) Television Talk Shows. Discourse, Performance, Spectacle (pp. 7-30). Mahwah, N.J.: Erlbaum.

Tsui, A. (1994). English Conversation. Oxford: Oxford University Press.

\section{Copyrights}

Copyright for this article is retained by the author(s), with first publication rights granted to the journal.

This is an open-access article distributed under the terms and conditions of the Creative Commons Attribution license which permits unrestricted use, distribution, and reproduction in any medium, provided the original work is properly cited. 